\title{
PERSISTENCE OF SARS-COV-2 IN DECEASED PATIENTS AND SAFE HANDLING OF INFECTED BODIES
}

Shchegolev $\mathrm{Al}^{1,2}$, Tumanova $\mathrm{UN}^{1}$

${ }^{1}$ Kulakov National Medical Research Centre of Obstetrics, Gynecology and Perinatology, Moscow, Russia

2 Pirogov Russian National Research Medical University, Moscow, Russia

This article analyzes the literature on SARS-CoV-2 persistence in the corpses of patients infected with COVID-19, possible routes of viral transmission from the bodies and biosafety measures to prevent the spread of the infection. SARS-CoV-2 persists for quite long in the tissues and bodily fluids of decedents with COVID-19 and on various surfaces. The longest viability of the virus is on stainless steel and plastic surfaces that come in contact with the infected body. Autopsies on decedents with COVID-19 must be performed at specially conditioned facilities. Medical and forensic pathologists and other mortuary workers must adhere to stringent biosafety requirements.

Keywords: COVID-19, SARS-CoV-2, persistence, corpse, autopsy, biosafety

Author contribution: Shchegolev Al designed the study, searched and analyzed the literature and wrote the manuscript; Tumanova UN searched and analyzed the literature and wrote the manuscript.

$\triangle$ Correspondence should be addressed: Alexander I. Shchegolev Akademika Oparina, 4, Moscow, 117485; patan777@gmail.com

Received: 31.05.2021 Accepted: 14.06.2021 Published online: 18.06.2021

DOI: 10.24075/brsmu.2021.029

\section{ПЕРСИСТЕНЦИЯ КОРОНАВИРУСА SARS-COV-2 В ТЕЛАХ УМЕРШИХ И МЕРЫ ЗАЩИТЫ ОТ ИНФИЦИРОВАНИЯ}

\author{
А. И. Щеголев ${ }^{1,2}$, У. Н. Туманова ${ }^{1}$ \\ ${ }^{1}$ Национальный медицинский исследовательский центр акушерства, гинекологии и перинатологии имени В. И. Кулакова, Москва, Россия \\ 2 Российский национальный исследовательский медицинский университет имени Н. И. Пирогова, Москва, Россия
}

\begin{abstract}
Представлен анализ данных литературы о времени coxранения SARS-CoV-2 в телах умерших, путях заражения от трупов больных с COVID-19 и необходимых способах защиты от такого заражения. Показано, что для SARS-CoV-2 характерен достаточно длительный период персистенции в тканях и жидкостях тел умерших больных с COVID-19, а также на различных поверхностях, при этом наиболее долго вирус сохраняется на стальных и пластиковых изделиях, находившихся в соприкосновении с трупом. Согласно проанализированным данным, вскрытие тел умерших больных с COVID-19 должно проходить только в специально перепросилированных отделениях с обязательным соблюдением мер, обеспечивающих биологическую безопасность, сотрудники патологоанатомических отделений и бюро судебно-медицинской экспертизы обязаны соблюдать при этом меры индивидуальной и коллективной защиты.
\end{abstract}

Ключевые слова: COVID-19, SARS-CoV-2, персистенция, труп, аутопсия, меры защиты

Вклад авторов: А. И. Щеголев - дизайн обзора, поиск и анализ данных литературы, редактирование текста; У. Н. Туманова — поиск и анализ данных литературы, написание текста.

$\bowtie$ Для корреспонденции: Александр Иванович Щеголев

ул. Академика Опарина, д. 4, г. Москва, 117485; patan777@gmail.com

Статья получена: 31.05.2021 Статья принята к печати: 14.06.2021 Опубликована онлайн: 18.06.2021

DOI: $10.24075 /$ vrgmu.2021.029

The novel coronavirus infection (2019-nCoV, novel coronavirus disease 2019, abbreviated COVID-19) was first officially reported in 2019 in Wuhan, China. By August 2020, the infection had spread to 213 countries [1]. As of January 1 and May 1, 2021, there were a total of 84,092,619 and 152,196,159 diagnosed COVID-19 cases worldwide, respectively [2].

Approximately $20 \%$ of individuals infected with SARSCoV-2 were hospitalized; of them, about 20\% needed intensive care [3]. Of those needing intensive care, 50-80\% died; this figure corresponds to $2-4 \%$ mortality in countries with resourceful healthcare systems. At the same time, death rates from the coronavirus varied across the world from $0.1 \%$ to $14 \%$ in May 2020 and from 1.5\% to 14\% in July 2020. [1]. By May 1, 2021 the total death toll from COVID-19 had reached 3,192,763 [2]. Naturally, healthcare workers and the relatives of COVID-19 victims come in contact with the bodies of the decedents.

One of the most serious challenges facing the medical community today is to understand how the virus can be contracted from the bodies of deceased persons with confirmed or suspected COVID-19.

\section{Routes of microbial transmission from corpses}

Throughout its history, mankind has suffered from infectious diseases, including life-threatening infections characterized by high mortality rates. The bodies of diseased individuals have always been thought to be a potential source of infection, and their handling required additional biosafety measures [4].

For example, skin and mucosal infections caused primarily by Streptococcus pyogenes (a group A pathogen) and methicillin-resistant Staphylococcus aureus (MRSA) can be transmitted through direct contact with the infected skin of the decedent or contaminated fomites. There is a risk of contracting noxious microorganisms, like Salmonella typhi, which causes typhoid fever, and Hepatovirus $A$, the causative agent of viral hepatitis $A$, through direct contact with the stools of the infected person or contaminated fomites.

Airborne transmission is typical for Mycobacterium tuberculosis; therefore, autopsy suite staff and morgue workers are at high risk for tuberculosis [5]. The increased risk of TB among funeral home workers handling the bodies of TB-afflicted individuals is inferred from their tuberculin skin 
test results [6]. Notably, formalin used for tissue fixation is a tuberculocidal agent.

Direct contact with blood or other bodily fluids coming, among other things, from skin wounds can result in contracting hepatitis B, C (Hepacivirus $B$ and $C$ ) and AIDS-causing HIV (Human Immunodeficiency Virus) [4]. Viable HIV was isolated from the bone fragments, spleen, brain, bone marrow and lymph nodes of an AIDS patient during the autopsy performed 6 days postmortem [7]. Moreover, HIV was detected in the pleural and pericardial effusions and blood of human corpses stored at $2{ }^{\circ} \mathrm{C}$ for 16.5 days after death [8]. Direct contact with infected bodily fluids like blood, saliva, sweat, or urine can result in the transmission of Ebola virus (Ebolavirus), Marburg virus (Marburgvirus) and Lassa hemorrhagic fever (Lassa mammarenavirus), all of which are endemic to Africa.

The decision to perform an autopsy on a patient who fell victim to an infectious disease was always based on the careful consideration of the causative agent, biosafety and the existing policies on human autopsies.

In the USSR, an autopsy was mandatory in the case of death from a highly infectious disease, and the organs of the decedent were subjected to a histopathological and bacteriological/virological examination [9]. However, autopsies were prohibited if death was caused by anthrax (regardless of its form) bacteriologically confirmed during life. Today, an autopsy is mandatory in the case of death from a suspected or confirmed infectious disease [10].

\section{Autopsy and SARS-CoV-2}

SARS-CoV-2 is a representative of group II pathogens, i.e. those that cause highly contagious epidemic diseases in humans. In Russia, autopsies are performed on all deceased individuals with COVID-19.

That said, some foreign authors think that it is unreasonable to perform an autopsy on a patient infected with SARS-CoV-2. For instance, some Polish forensic pathologists hold the opinion that there are no medical indications for autopsy in the case of death from confirmed SARS-CoV-2 [11]. Italian researchers think that autopsy on a COVID-19 patient should be well-justified, but propose no criteria for such justification [12].

Interestingly, medical autopsies are not performed routinely in China. At the outset of the epidemic in China, the bodies of patients with COVID-19 were not autopsied, but later administrative authorization was obtained to perform autopsies on COVID-19 patients, with strict adherence to biosafety guidelines. However, at that time there were not enough autopsy suites in Wuhan meeting the stringent biosafety requirements [13].

In the spring of 2020, there was a surge in COVID-19 cases in Italy. On April 1, 2020 the Ministry of Healthcare of Italy issued a recommendation to avoid autopsies or postmortem diagnostic examinations on corpses infected COVID-19 [14].

At the outset of the epidemic, the Robert Koch Institute, one of the leading research facilities in Germany, advised against performing autopsies on patients with COVID-19; so postmortem examinations were carried out only in some parts of the country [15]. However, in Hamburg, the second largest German city with 1.8 million population, all necessary arrangements were made in the early stage of the epidemic to ensure that full autopsies could be performed on COVID-19 victims [15].

Despite the diversity of opinions and autopsy policies, one of the major arguments in favor of autopsies during the coronavirus pandemic is the need to determine the exact cause of death, be it COVID-19 or a preexisting condition. Besides, the main body of knowledge about morphological changes and organ pathology associated with COVID-19 came from the autopsies and full pathomorphological examinations of COVID-19 patients' organs and tissues.

So far, we know that COVID-19 is caused by SARS-CoV-2, one of 7 human coronaviruses [16]. This enveloped singlestranded RNA $\beta$-coronavirus has the largest genome known and a crown-like appearance visible under a microscope.

Similar to other coronaviruses, SARS-CoV-2 has 4 basic structural components: spikes (S), a membrane (M), an envelope (E) and a nucleocapsid (N). It has been established that the $\mathrm{S}$ protein helps the virus latch onto and enter the host cell. The $\mathrm{C}$-terminal domain of the $\mathrm{S}$ protein binds to a human angiotensin converting enzyme 2 (hACE2) receptor expressed on the cell surface and thus mediates fusion of the virus membrane and the plasma membrane of the host cell, resulting in endocytosis and infection [17].

This mechanism is analogous to that employed by SARSCoV, but according to electronic microscopy data, the affinity of the SARS-CoV-2 S protein for ACE2 is 10-20 times higher than that of SARS-CoV [18], which presumably determines the high transmissibility of the novel coronavirus.

A study has identified potential routes of entry and target sites for SARS-CoV-2 based on the information about the sites of ACE2 expression [19]. ACE2 is expressed in the alveolar type II cells of the lungs, cardiomyocytes, the epithelial lining of the renal proximal tubule, the esophagus, ileal epithelial cells, the epithelium of the urinary bladder, lymph nodes, the thymus, the bone marrow, the spleen, the liver and the brain [20]. ACE2 receptors also occur on the surface of keratinocytes, fibroblasts, endothelial cells, osteoblasts and osteoclasts.

Consequently, autopsies followed by immunohistological and molecular biological analysis were instrumental in describing changes to the organs and tissues of COVID-19 patients, mapping them against infection sites and the sites of SARS-CoV-2 receptors and determining the time interval during which the viral RNA is present in the tissues of a dead infected patient.

Coronaviruses have been known to persist in the organs and tissues of dead infected patients since 2007 [21]. A comparative postmortem analysis of viral load in the internal organs of 7 patients who had died from severe acute respiratory syndrome (SARS) revealed that the SARS-CoV/GAPDH RNA ratio was the highest $(\geq 1)$ in the lungs and small bowel and was $<1$ in the heart, spleen and kidneys. Time from death to tissue sampling for PCR was 90-180 h. Unfortunately, the researchers failed to find out how virulent the viral particles were [21].

Reportedly, SARS-CoV-2 is detected in the organs and tissues of dead patients who tested positive for this virus during life. For example, of all nasopharyngeal swabs collected from 29 patients with COVID-19 2-24 h postmortem, 10 were positive for SARS-CoV-2 $2 \mathrm{~h}$ and $4 \mathrm{~h}$ after death, 9 were positive $6 \mathrm{~h}$ after death and 7 were positive $12 \mathrm{~h}$ postmortem [22]. Remarkably, the nasopharyngeal swabs obtained from the forensic pathologists performing the autopsies were all negative. Another study compared the results of antemortem and postmortem nasopharyngeal COVID-19 swab testing [23]. Antemortem swabs were collected 2-14 days before death. Comparison of SARS-CoV-2 RNA levels in the obtained specimens demonstrated the high viability of the viral RNA in the bodies within 2.7-482.6 $\mathrm{h}$ after death. The authors note that all patients had pronounced immunosuppression and their bodies were refrigerated and kept at $4{ }^{\circ} \mathrm{C}$ before being autopsied [23]. 
Another study detected SARS-CoV-2 RNA in the bodies of 4 patients with SARS-CoV-2 infection confirmed during life: a full autopsy was performed followed by real-time PCR analysis of the obtained tissue specimens. SARS-CoV-2 RNA was detected in the lung tissue of each body [24]. Besides, one of the decedents had SARS-CoV-2 RNA in their brain, another had the virus in the small intestine and the kidney. Notably, time between the autopsy and death varied from 1 to 17 days.

SARS-CoV-2 might persist in the eyes, specifically in the retina and the vitreous body [25]. A study reports that 2 of 10 vitreous body swabs collected from patients with COVID-19 were positive for SARS-CoV-2 RNA. Importantly, the viral RNA persisted in the vitreous body even after the specimens were stored at $-20{ }^{\circ} \mathrm{C}$ and then thawed.

There is an interesting case of a 60-year-old male hospitalized after a fall at home; the man died in the hospital the next day [26]. The preliminary cause of death was SARSCoV-2-associated pneumonia; the infection was comorbid with Steinert's disease and ischemic cardiomyopathy. After death the patient's body was stored at $4{ }^{\circ} \mathrm{C}$ awaiting cremation, which was performed 35 days later. Before cremation, a forensic pathologist collected nasal and oropharyngeal swabs from the decedent; real-time PCR performed the same day, i.e. 35 days after death, detected the presence of SARS-CoV-2 RNA in the swabs. The authors of the cited article think that the long persistence of SARS-CoV-2 RNA could be explained by the absence of antiviral therapy and the temperature of the mortuary refrigerator $\left(4^{\circ} \mathrm{C}\right)[28]$.

SARS-CoV-2 was also detected in the decomposing tissues of a human corpse subjected to a postmortem examination 17 days after death [24]. There is a report of SARS-CoV-2 presence in necrotic placental villi collected from a pregnant woman with COVID-19; the virus was detected immunohistochemically in the reaction with anti-SARS-CoV-2 Nucleocapsid antibodies [27].

Coronaviruses can persist on non-biological surfaces like metal, plastic, paper, and glass [28]. The endemic human coronavirus strain HCoV-229E remains infectious on different types of surfaces from $2 \mathrm{~h}$ to 9 days. TGEV (transmissible gastroenteritis virus) and MHV (mouse hepatitis virus) are reported to persist for up to 28 days at $4{ }^{\circ} \mathrm{C}$. At higher temperatures $\left(30^{\circ} \mathrm{C}\right.$ or $\left.40^{\circ} \mathrm{C}\right)$, the duration of highly pathogenic MERS-CoV (Middle East respiratory syndrome coronavirus), TGEV and MHV is shorter. At room temperature, HCoV-229E persists longer at $50 \%$ vs $30 \%$ relative humidity.

A comparative study of stability and decay rates of SARSCoV-2 and SARS-CoV-1 in aerosols and on 4 different surfaces (plastic, stainless steel, copper and cardboard) showed that SARSCoV-2 remained viable in aerosols for $3 \mathrm{~h}$, but its tissue-culture infectious dose TCID50, which kills 50\% of monolayer cells, was decreasing over time from 103.5 to 102.7 per liter of air. For SARSCoV-1, TCID50 went down from 104.3 to 103.5 per liter of air.

At the same time, viable SARS-CoV-2 was detected on plastic and stainless steel after $72 \mathrm{~h}$ and $48 \mathrm{~h}$, respectively, with TCID50 falling from 103.7 to 100.6 per milliliter of medium. The dynamics of SARS-CoV-1 concentrations were the same. On cardboard and copper, no viable SARS-CoV-2 was detected after $24 \mathrm{~h}$ and $4 \mathrm{~h}$, respectively; viable SARS-CoV-1 was no longer detected on these surfaces after $8 \mathrm{~h}$ [29]. For SARSCoV-2, the longest viability was on stainless steel and plastic. These are the materials dissection tables, autopsy instruments and body bags are made of. This is an important factor that needs to be accounted for when developing biosafety and disinfection guidelines for autopsy suites.

An example to illustrate this point is an incident with the Diamond Princess cruise ship: SARS-CoV-2 RNA was detected on various surfaces in the cabins 17 days after all symptomatic and asymptomatic patients with COVID-19 had come ashore [30]. Of 3,711 passengers and crew members, 712 (19.2\%) tested positive for SARS-CoV-2; of them 331 (46.5\%) had no clinical symptoms at the time of testing.

It should be born in mind that viral transmission is determined by the type of the virus and the duration of contact. It is reported that $31.6 \%$ of influenza $A$ virus and $1.5 \%$ of parainfluenza virus was transferred from the surface contaminated with influenza A and parainfluenza, respectively, to a hand during a 5-second-long contact between the hand and the surface [31]. Interestingly, students touch their faces 23 times an hour on average; skin is the most touched organ (56\%), followed by the mouth (16\%), nose (14\%) and eyes (12\%) [28].

Unfortunately, despite a wealth of reports, there is no clarity on how long the novel coronavirus persists in the organs and tissues of deceased patients with COVID-19, and no clear correlations between the results of PCR testing for SARS-CoV-2 RNA and the results of culture tests have been established. Post- and antemortem studies of tissue samples collected from patients with COVID-19 could shed more light on these issues [32].

Considering that organs and tissues of deceased individuals with COVID-19, as well as equipment, instruments and other items used for their transportation, storage and autopsying, may contain or be contaminated with viral particles, they can be the source of infection for autopsy suite staff and funeral home workers. SARS-CoV-2 is transmitted via respiratory droplets, through direct contact, via the fecal-oral and airborne routes.

Although there are few reports of COVID-19 infection among dissection room staff unsupported by strong evidence of SARS-CoV-2 transmission during autopsies [33], deaths of medical and forensic pathologists who performed autopsies on "red zone" patients suggest that such transmission is highly probable.

\section{Biosafety measures against SARS-CoV-2}

This leads us to conclude that the respiratory tract specimens of any human corpse must be PCR-tested for SARS-CoV-2 to ensure safety of autopsy suite staff [34]. A positive SARSCoV-2 test is not a pretext for not performing an autopsy; it is a warning that adequate biosafety measures should be taken to protect the personnel.

All foreign and Russian guidelines on the safe handling of deceased persons with COVID-19 prescribe that personal protective equipment (PPE), i.e. gloves and a disposable gown, should be worn by the involved staff (see Table). Additionally, in some countries, including China [35] and India [36], a waterresistant apron, googles and a face shield must be worn. A body of a patient with COVID-19 must be transported to a morgue as soon as possible. According to Chinese [35] and Indian [36] guidelines, the skin of the deceased person must be disinfected; wounds must be disinfected and dressed with impermeable material. Natural body orifices, including the mouth, nose and anus, must be plugged. In accordance with Russian guidelines, all natural body orifices must be plugged with cotton balls and wounds must be dressed with gauze soaked in a 3,000-5,000 mg/L chlorine-based disinfectant or $0.5 \%$ peracetic acid [43].

In most countries, bodies are transported to morgues in leak-proof plastic body bags to prevent contact with the body or bodily fluids. In China [35] and India [36] body bags must be wrapped in a mortuary sheet. According to Indian guidelines, corpses infected with SARS-CoV-2 must be stored separately 
Table. Personal protective equipment recommended for staff involved in the handling and autopsying of dead bodies of patients with COVID-19

\begin{tabular}{|c|c|c|c|c|c|}
\hline Source & Standard PPE & Water-resistant apron & Face shield & Googles & Double gloves \\
\hline \multicolumn{6}{|c|}{ No autopsy performed } \\
\hline China [35] & + & + & + & + & \\
\hline India [36] & + & + & + & + & \\
\hline USA [37] & + & & + & + & \\
\hline Netherlands [38] & + & & - & - & \\
\hline UK [39] & + & & + & + & \\
\hline Europe [40] & + & & & & \\
\hline WHO [41] & + & + & + & + & \\
\hline \multicolumn{6}{|c|}{ During autopsy } \\
\hline China [35] & + & + & + & . & + \\
\hline India [36] & + & + & + & + & + \\
\hline USA [37] & + & + & + & + & + \\
\hline UK [39] & + & + & + & + & + \\
\hline Germany [42] & + & + & + & + & + \\
\hline Europe [40] & + & & + & + & + \\
\hline WHO [41] & + & + & + & + & + \\
\hline
\end{tabular}

Note: standard PPE are gloves, a disposable gown and hand hygiene.

from SARS-CoV-2 negative bodies in a room fitted with an autonomous ventilation system [36]. In Germany, the body of a patient with COVID-19 must be wrapped in a double-layer sheet treated with a disinfectant, placed into a double-layer leak-proof bag and then placed into a casket, which must be immediately sealed [42].

A pathologist must follow stringent biosafety guidelines while performing an autopsy on a COVID-19 patient. In our opinion, Russia can boast the most effective biosafety measures for the handling of dead bodies with COVID-19. The Ministry of Healthcare of Russia requires that autopsies on COVID-19 patients should be performed at specially conditioned facilities [44]. In Moscow, some anatomic pathology units have been modernized to ensure compliance with the biosafety guidelines of the Russian Ministry of Healthcare [45].

In Russia, autopsies must be conducted in a negative pressure room with 6 air changes per hour (for existing facilities) or 12 air changes per hour (for newly built or renovated facilities); air must be exhausted directly outside or HEPA-filtered [43]. In UK [39] and India [36] autopsies must be performed in a properly ventilated negative pressure room fitted with a downdraught table. In Germany, autopsies must be performed in a separate building with autonomous sewage and ventilation systems and shower cabins for staff [42].

In Russia, the number of people in the dissection room must be limited to those participating in autopsying and tissue sampling, i.e. a pathologist, a laboratory assistant and a diener. Medical and forensic autopsies of persons with COVID-19 must be performed in the presence of a federal state sanitary and epidemiological surveillance representative [43]. However, this requirement does not apply to the anatomic pathology units of Moscow specially conditioned for autopsying COVID-19 patients and authorized for such procedures by Rospotrebnadzor [45]. The autopsy itself is performed and supervised by the head of the unit or the most experienced pathologist [43]. Paradoxically, some foreign researchers think that experienced autopsy pathology trainees, including pregnant trainees, can be recruited for autopsies on COVID-19 patients [46].

All foreign guidelines require that a pathologist performing an autopsy should wear standard PPE, including gloves and a disposable gown, and practice good hand hygiene (see Table). In Germany [42] and India [36], the standard PPE set is complemented by double gloves. In the USA [37], UK [39] and Germany [42], a protective whole-body gown and vented respirators are recommended.

According to Russian guidelines [43], a pathologist involved in autopsying a person with COVID-19 must wear:

- double surgical gloves with a layer of cut-proof synthetic mesh;

- a disposable water-resistant or impermeable long-sleeved protective garment (a surgical scrub suit, a gown);

- a water-resistant apron;

- a plastic face shield or googles to protect the face and the eyes from splashes of fluid;

- a disposable respirator with the high level of respiratory protection;

- disposable shoe covers, a surgical cap.

Alternatively, a pathologist can wear type I or || biohazard suit and "Quartz" PPE or type II biohazard suit plus double surgical gloves with a layer of cut-proof synthetic mesh, googles, an oilcloth or polyethylene apron, protective sleeve covers and an FFP3 respirator. Quartz-1M protective wear for infectious disease specialists is also recommended [44].

Most guidelines advise against procedures accompanied by inadvertent splashes (from high-pressure water jets or placing a cadaver in the water) and aerosol generation or recommend they should be minimized. Russian guidelines suggest the "dry autopsy" approach [43-45]. Using an oscillating saw is not recommended or the saw should be attached to a vacuum shroud to contain bone dust; biological specimen should be collected using a sterile instrument set.

In India [36], UK [39] and Germany [42] autopsies are performed by dissecting body cavities consecutively. Some researchers suggest that a staged autopsy protocol should be applied [46]: first, a biological specimen is collected for SARSCoV-2 testing and then a full autopsy is carried out.

Some international authors insist on a minimally invasive autopsy in the case of a COVID-19 patient: tissue and fluid specimens are collected based on antemortem and/or postmortem radiographic data $[13,47]$. CT complemented by a histopathological examination is increasingly employed for 
postmortem imaging of lung tissue in adult patients [48, 49]. In the case of a neonatal death, a postmortem MRI examination is recommended, since it can effectively and reliably verify congenital pneumonia $[50,51]$. Postmortem ultrasonography can be used to accurately collect tissue specimens while minimizing the risk of infection at autopsy [52]. However, in order to prevent artifacts, postmortem ultrasonography should be conducted no sooner than 1-2 $\mathrm{h}$ after the body has been retrieved from the mortuary refrigerator and reached room temperature [52].

The final stage of any autopsy involves disinfection of the cadaver's skin, medical instruments and the dissection room itself. For skin disinfection, sodium hypochlorite (1\% or $5.25 \%)$ is recommended. All surfaces that come in contact with the dead body must be cleared of all visible stains and decontaminated with sodium hypochlorite or $70 \%$ ethanol. In Germany, it is prohibited to drain wastewater down the shared drain [42], and air in the dissecting room must be disinfected with an ultraviolet lamp for $1 \mathrm{~h}$ and filtered for $2 \mathrm{~h}$ [42].

Russian researchers [43-45] advise against embalming; instead, the body should be placed in a plastic body bag, the outer surface of the bag should be disinfected and left in the storage room until the funeral. Before the body is collected by the relatives, it should be placed in the second plastic bag, the outer surface of the bag should be disinfected, and then placed into a casket, which should be then sealed for further burying or cremation. In China [35] and India [36] the embalming of bodies infected with COVID-19 is prohibited. Almost in every country a physical contact with the body is not recommended, except the Netherlands [38], where touching is allowed, providing that good hand hygiene is practiced. In China, the bodies of patients with COVID-19 are subjected to cremation [35]; in Germany, it is allowed to bury the bodies if the grave is at least $2 \mathrm{~m}$ deep [42].

\section{CONCLUSION}

SARS-CoV-2 persists for quite long in the tissues and bodily fluids of decedents with COVID-19 and on various surfaces that come in contact with the infected deceased person. The longest viability of the virus is on stainless steel and plastic surfaces. Autopsies on decedents with COVID-19 must be performed at specially conditioned facilities ensuring biosafety of the involved personnel. Medical and forensic pathologists and other mortuary workers must adhere to stringent biosafety requirements imposed by the existing guidelines.

\section{References}

1. Matta S, Chopra KK, Arora VK. Morbidity and mortality trends of Covid 19 in top 10 countries. Indian J Tuberc. 2020; 67 (4S): S167-S172.

2. Publichnyj dashbord Yandex DataLens. Available from: https://datalens.yandex/7o7is1 q6ikh23?tab=0Ze\&utm source $=$ cbmain\&state $=7$ e29b15887.

3. Sekhawat V, Green A, Mahadeva U. COVID-19 autopsies: conclusions from international studies. Diagn Histopathol (Oxf). 2021; 27 (3): 103-7.

4. Aubert AC, Lampurlanés XS. Servicios funerarios: exposición laboral a agentes biológicos. Notas Técnicas de Prevenció. 2010; 858: 1-6.

5. Sterling TR, Pope DS, Bishai WR, Harrington S, Gershon RR, Chaisson RE. Transmission of mycobacterium tuberculosis from a cadaver to an embalmer. N Engl J Med. 2000; 342 (4): 246-8.

6. Gershon RR, Vlahov D, Escamilla-Cejudo JA, Badawi M McDiarmid M, Karkashian C. et al. Tuberculosis risk in funeral home employees. J Occup Environ Med. 1998; 40 (5): 497-503.

7. Nyberg M, Suni J, Haltia M. Isolation of human immunodeficiency virus infection in health care workers. Arch Intern Med. 1990; 153: 1451-8.

8. Douceron H, Deforges L, Gherardi R, Sobel A, Chariot P. Longlasting postmortem viability of human immunodeficiency virus: A potential risk in forensic medicine practice. Forensic Sci Int. 1993; 60 (1-2): 61-6.

9. Instrukcii o protivojepidemicheskom rezhime raboty s materialom, zarazhennym ili podozritel'nym na zarazhennost' vozbuditeljam chumy, holery, sapa, melioidoza, natural'noj ospy, sibirskoj jazvy, tuljaremii i brucelleza, Ministerstvo zdravoohranenija SSSR. AlmaAta, 1975.

10. Federal'nyj zakon "Ob osnovah ohrany zdorov'ja grazhdan v Rossijskoj Federacii" ot 21.11.2011 N 323-FZ.

11. Teresiński G, Jurek T. Recommendations of the polish society of forensic medicine and criminology and national consultant for forensic medicine with regard to performing forensic post-mortem examinations in case of confirmed COVID-19 disease and suspected SARS CoV-2 infections. Arch Med Sadowej Kryminol. 2019; 69 (4): 147-57.

12. Sapino A, Facchetti F, Bonoldi E, Gianatti A, Barbareschi M, Società Italiana di Anatomia Patologica e Citologia - SIAPEC. The autopsy debate during the COVID-19 emergency: the Italian experience. Virchows Arch. 2020; 476 (6): 821-3,

13. Tian S, Xiong Y, Liu H, Niu L, Guo J, Liao M, et al. Pathological

study of the 2019 novel coronavirus disease (COVID-19) through postmortem core biopsies. Mod Pathol. 2020; 33 (6): 1007-14.

14. Moretti M, Malhotra A, Visonà SD, Finley SJ, Osculati AMM, Javan GT. The roles of medical examiners in the COVID-19 era: a comparison between the United States and Italy. Forensic Sci Med Pathol. 2021; 17 (2): 262-70.

15. Sperhake JP. Autopsies of COVID-19 deceased? Absolutely! Leg Med (Tokyo). 2020; 47: 101769.

16. Zhu N, Zhang D,Wang W, Li X, Yang B, Song J, et al. A novel coronavirus from patients with pneumonia in China, 2019. N Engl J Med. 2020; 382 (8): 727-33.

17. He F, Deng Y, Li W. Coronavirus disease 2019: What we know? J Med Virol. 2020; 92 (7): 719-25.

18. Wrapp D, Wang N, Corbett KS, Goldsmith JA, Hsieh CL, Abiona O, et al. Cryo-EM structure of the 2019-nCoV spike in the prefusion conformation. Science. 2020; 367 (6483): 1260-3.

19. Xu H, Zhong L, Deng J, Peng J, Dan H, Zeng X, et al. High expression of ACE2 receptor of 2019-nCoV on the epithelial cells of oral mucosa. Int J Oral Sci. 2020; 12 (1): 8.

20. Zou X, Chen K, Zou J, Han P, Hao J, Han Z. Single-cell RNAseq data analysis on the receptor ACE2 expression reveals the potential risk of different human organs vulnerable to 2019-nCoV infection. Front Med. 2020; 14 (2): 185-92.

21. Tang JW, To KF, Lo AW, Sung JJ, Ng HK, Chan PK. Quantitative temporal-spatial distribution of severe acute respiratory syndrome-associated coronavirus (SARSCoV) in post-mortem tissues. J Med Virol. 2007; 79 (9): 1245-53.

22. Aquila I, Ricci P, Bonetta CF, Sacco MA, Longhini F, Torti C, et al Analysis of the persistence time of the SARS-CoV-2 virus in the cadaver and the risk of passing infection to autopsy staff. Med Leg J. 2021; 89 (1): 40-53.

23. Heinrich F, Meißner K, Langenwalder F, Püschel K, Nörz D, Hoffmann A, et al. Postmortem stability of SARS-CoV-2 in nasopharyngeal mucosa. Emerg Infect Dis. 2021; 27 (1): 329-31.

24. Plenzig S, Bojkova D, Held H, Berger A, Holz F, Cinatl J, et al. Infectivity of deceased COVID-19 patients. Int J Legal Med. 2021 Mar 5; 1-6.

25. Bogdanović M, Skadrić I, Atanasijević T, Stojković O, Popović $\mathrm{V}$, Savić S, et al. Case Report: Post-mortem histopathological and molecular analyses of the very first documented COVID-19related death in Europe. Front Med. 2021; 8: 612758. 
26. Beltempo P, Curti SM, Maserati R, Gherardi M, Castelli M. Persistence of SARS-CoV-2 RNA in post-mortem swab 35 days after death: A case report. Forensic Sci Int. 2021; 319: 110653

27. Sukhikh G, Petrova U, Prikhodko A, Starodubtseva N, Chingin K, Chen $\mathrm{H}$, et al. Vertical transmission of SARS-CoV-2 in second trimester associated with severe neonatal pathology. Viruses. 2021; 13: 447.

28. Kampf G, Todt D, Pfaender S, Steinmann E. Persistence of coronaviruses on inanimate surfaces and their inactivation with biocidal agents. J Hosp Infect. 2020; 104 (3): 246-51.

29. van Doremalen N, Bushmaker T, Morris DH, Holbrook MG, Gamble A, Williamson BN, et al. Aerosol and surface stability of SARS-CoV-2 as compared with SARS-CoV-1. N Eng J Med. 2020; 382 (16): 1564-7.

30. Leah FM, Plucinski MM, Marston BJ, Kurbatova EV, Knust B, Murray EL, et al. Public health responses to COVID-19 outbreaks on cruise ships - worldwide, February-March 2020. MMWR Morb Mortal Wkly Rep. 2020; 69 (12): 347-52.

31. Ansari SA, Springthorpe VS, Sattar SA, Rivard S, Rahman M. Potential role of hands in the spread of respiratory viral infections: studies with human parainfluenza virus 3 and rhinovirus 14. J Clin Microbiol. 1991; 29 (10): 2115-9.

32. Cevik M, Tate M, Lloyd O, Maraolo AE, Schafers J, Ho A. SARSCoV-2, SARS-CoV, and MERS-CoV viral load dynamics, duration of viral shedding, and infectiousness: a systematic review and meta-analysis. Lancet Microbe. 2021; 2: e13-22.

33. Davis GG, Williamson AK. Risk of Coronavirus Disease 2019 transmission during autopsy. Arch Pathol Lab Med. 2020; 144 (12): $1445 a-1445$.

34. Nakamura M, Tojo M, Takaso M, Hitosugi M. A regional approach for infection prevention in death investigations during the COVID-19 era. Leg Med (Tokyo). 2021; 48: 101829.

35. Centre for Health Protection. Precautions for Handling and Disposal of Dead Bodies, Hong Kong, China, 2020. Available from: https://www.chp.gov.hk/files/pdf/grp-guideline-hp-icprecautions_for_handling_and_disposal_of_dead_bodies_en.pdf.

36. Government of India Ministry of Health \& Family Welfare Directorate General of Health Services. COVID-19: Guidelines on dead body management, India, 2020. Available from: https://www.mohfw. gov.in/pdf/1584423700568_COVID19GuidelinesonDeadbodyma nagement.pdf.

37. Centers for Disease Control and Prevention. Collection and Submission of Postmortem Specimens from Deceased Persons with Known or Suspected COVID-19 (Postmortem Guidance). Available from: https://www.cdc.gov/coronavirus/2019-ncov/ hcp/guidance-postmortem-specimens.html.

38. Rijksinstituut voor Volksgezondheid en Milieu. COVID-19 richtlijn (guideline). Available from: https://lci.rivm.nl/richtlijnen/covid-19.

39. Health and Safety Executive. Managing infection risks when handling the deceased. Guidance for the mortuary, post-mortem room and funeral premises, and during exhumation. Available from: https://www.hse.gov.uk/pUbns/priced/hsg283.pdf.

40. European Centre for Disease Prevention and Control. Considerations related to the safe handling of bodies of deceased persons with suspected or confirmed COVID-19, Europe, 2020. Available from: https://www.ecdc.europa.eu/en/publications-data/ considerations-related-safe-handling-bodies-deceased-personssuspected-or.

41. WHO Guidelines. Infection prevention and control of epidemic- and pandemic-prone acute respiratory infections in health care - WHO Guidelines. Available from: https://apps.who.int/iris/bitstream/ha ndle/10665/112656/9789241507134_eng.pdf?sequence=1 .

42. Keten D, Okdemir E, Keten A. Precautions in postmortem examinations in Covid-19 - Related deaths: Recommendations from Germany. J Forensic Leg Med. 2020; 73: 102000.

43. Frank GA, Kovalev AV, Gribunov YuP, Zaslavskij Gl, Kildjushov EM, Jagmurov OD, i dr. Issledovanie umershih $s$ podozreniem na koronavirusnuju infekciju (COVID-19). V sbornike: Vremennye metodicheskie rekomendacii. Versija 22 (23.07.2020). M., 2020; 428 s. Russian.

44. Vremennye metodicheskie rekomendacii: profilaktika, diagnostika i lechenie novoj koronavirusnoj infekcii (COVID-19). Versija 10 (08.02.2021). M., 2021; 262 s. Russian.

45. Zajratyanc OV, Kanibolockij AA, Mihaleva LM, Mishnev OD, Savelov NS, Avdalyan AM, i dr. Novaja koronavirusnaja infekcija (COVID-19). Organizacija raboty patologoanatomicheskoj sluzhby. V sbornike: Vremennye metodicheskie rekomendacii. Versija 3 (15.11.2020). M., 2020; 36 s. Russian.

46. Hanley B, Lucas SB, Youd E, Swift B, Osborn M. Autopsy in suspected COVID-19 cases. J Clin Pathol. 2020; 73: 239-42.

47. Monteiro RAA, Duarte-Neto AN, Silva LFFD, Oliveira EP, Filho JT, Santos GABD, et al. Ultrasound-guided minimally invasive autopsies: A protocol for the study of pulmonary and systemic involvement of COVID-19. Clinics (Sao Paulo). 2020; 75: e1972.

48. Roberts IS, Benamore RE, Benbow EW, Lee SH, Harris JN, Jackson $A$, et al. Post-mortem imaging as an alternative to autopsy in the diagnosis of adult deaths: a validation study. Lancet. 2012; 379 (9811): 136-42.

49. Kniep I, Lutter M, Ron A, Edler C, Püschel $\mathrm{K}$, Ittrich $\mathrm{H}$, et al. Postmortem imaging of the lung in cases of COVID-19 deaths. Radiologe. 2020; 60 (10): 927-33.

50. Tumanova UN, Lyapin VM, Bychenko VG, Shchegolev AI, Sukhikh GT. Posmertnaja MRT dlja diagnostiki vrozhdennoj pnevmonii. Vestnik Rossijskogo gosudarstvennogo medicinskogo universiteta. 2016; 4: 48-55. Russian.

51. Tumanova UN, Shchegolev Al. Vozmozhnosti i ogranichenija virtual'noj autopsii v neonatologii. REJR. 2017; 7 (1): 20-33. Russian.

52. Kanchan T, Shrestha R, Krishan K. Post-mortem ultrasonography: a safer alternative to autopsies in COVID-19 deaths. J Ultrasound. 2020 Oct $31 ; 1-2$.

\section{Литература}

1. Matta S, Chopra KK, Arora VK. Morbidity and mortality trends of Covid 19 in top 10 countries. Indian J Tuberc. 2020; 67 (4S): S167-S172.

2. Публичный дашборд Yandex DataLens. Available from: https://datalens.yandex/7o7is1 q6ikh23?tab=0Ze\&utm _ source $=$ cbmain \&state $=7$ e29b 15887 .

3. Sekhawat V, Green A, Mahadeva U. COVID-19 autopsies: conclusions from international studies. Diagn Histopathol (Oxf). 2021; 27 (3): 103-7.

4. Aubert AC, Lampurlanés XS. Servicios funerarios: exposición laboral a agentes biológicos. Notas Técnicas de Prevenció. 2010; 858: 1-6.

5. Sterling TR, Pope DS, Bishai WR, Harrington S, Gershon RR, Chaisson RE. Transmission of mycobacterium tuberculosis from a cadaver to an embalmer. N Engl J Med. 2000; 342 (4): 246-8.

6. Gershon RR, Vlahov D, Escamilla-Cejudo JA, Badawi M, McDiarmid M, Karkashian C. et al. Tuberculosis risk in funeral home employees. J Occup Environ Med. 1998; 40 (5): 497-503.

7. Nyberg M, Suni J, Haltia M. Isolation of human immunodeficiency virus infection in health care workers. Arch Intern Med. 1990; 153: 1451-8.

8. Douceron H, Deforges L, Gherardi R, Sobel A, Chariot P. Longlasting postmortem viability of human immunodeficiency virus: $A$ potential risk in forensic medicine practice. Forensic Sci Int. 1993; 60 (1-2): 61-6.

9. Инструкции о противоэпидемическом режиме работы с материалом, зараженным или подозрительным на зараженность возбудителями чумы, холеры, сапа, мелиоидоза, натуральной оспы, сибирской язвы, туляремии и бруцеллеза, Министерство здравоохранения СССР. Алма-Ата, 1975.

10. Федеральный закон «Об основах охраны здоровья граждан в Российской Федерации» от 21.11.2011 N 323-ФЗ.

11. Teresiński $G$, Jurek $T$. Recommendations of the polish society of forensic medicine and criminology and national consultant for forensic medicine with regard to performing forensic post-mortem examinations in case of confirmed COVID-19 disease and suspected SARS CoV-2 infections. Arch Med Sadowej Kryminol. 2019; 69 (4): 147-57.

12. Sapino A, Facchetti F, Bonoldi E, Gianatti A, Barbareschi M, 
Società Italiana di Anatomia Patologica e Citologia - SIAPEC. The autopsy debate during the COVID-19 emergency: the Italian experience. Virchows Arch. 2020; 476 (6): 821-3

13. Tian S, Xiong Y, Liu H, Niu L, Guo J, Liao M, et al. Pathological study of the 2019 novel coronavirus disease (COVID-19) through postmortem core biopsies. Mod Pathol. 2020; 33 (6): 1007-14.

14. Moretti M, Malhotra A, Visonà SD, Finley SJ, Osculati AMM, Javan GT. The roles of medical examiners in the COVID-19 era: a comparison between the United States and Italy. Forensic Sci Med Pathol. 2021; 17 (2): 262-70.

15. Sperhake JP. Autopsies of COVID-19 deceased? Absolutely! Leg Med (Tokyo). 2020; 47: 101769

16. Zhu N, Zhang D,Wang W, Li X, Yang B, Song J, et al. A novel coronavirus from patients with pneumonia in China, 2019. N Engl J Med. 2020; 382 (8): 727-33.

17. He F, Deng Y, Li W. Coronavirus disease 2019: What we know? J Med Virol. 2020; 92 (7): 719-25

18. Wrapp D, Wang N, Corbett KS, Goldsmith JA, Hsieh CL, Abiona O, et al. Cryo-EM structure of the 2019-nCoV spike in the prefusion conformation. Science. 2020; 367 (6483): 1260-3.

19. Xu H, Zhong L, Deng J, Peng J, Dan H, Zeng X, et al. High expression of ACE2 receptor of 2019-nCoV on the epithelial cells of oral mucosa. Int J Oral Sci. 2020; 12 (1): 8

20. Zou X, Chen K, Zou J, Han P, Hao J, Han Z. Single-cell RNA seq data analysis on the receptor ACE2 expression reveals the potential risk of different human organs vulnerable to 2019-nCoV infection. Front Med. 2020; 14 (2): 185-92.

21. Tang JW, To KF, Lo AW, Sung JJ, Ng HK, Chan PK. Quantitative temporal-spatial distribution of severe acute respiratory syndrome-associated coronavirus (SARSCoV) in post-mortem tissues. J Med Virol. 2007; 79 (9): 1245-53.

22. Aquila I, Ricci P, Bonetta CF, Sacco MA, Longhini F, Torti C, et al. Analysis of the persistence time of the SARS-CoV-2 virus in the cadaver and the risk of passing infection to autopsy staff. Med Leg J. 2021; 89 (1): 40-53.

23. Heinrich F, Meißner K, Langenwalder F, Püschel K, Nörz D, Hoffmann A, et al. Postmortem stability of SARS-CoV-2 in nasopharyngeal mucosa. Emerg Infect Dis. 2021; 27 (1): 329-31.

24. Plenzig S, Bojkova D, Held H, Berger A, Holz F, Cinatl J, et al Infectivity of deceased COVID-19 patients. Int J Legal Med. 2021 Mar 5; 1-6.

25. Bogdanović M, Skadrić I, Atanasijević T, Stojković O, Popović V Savić S, et al. Case Report: Post-mortem histopathological and molecular analyses of the very first documented COVID-19related death in Europe. Front Med. 2021; 8: 612758.

26. Beltempo P, Curti SM, Maserati R, Gherardi M, Castelli M. Persistence of SARS-CoV-2 RNA in post-mortem swab 35 days after death: A case report. Forensic Sci Int. 2021; 319: 110653

27. Sukhikh G, Petrova U, Prikhodko A, Starodubtseva N, Chingin K Chen $\mathrm{H}$, et al. Vertical transmission of SARS-CoV-2 in second trimester associated with severe neonatal pathology. Viruses. 2021: 13: 447

28. Kampf G, Todt D, Pfaender S, Steinmann E. Persistence of coronaviruses on inanimate surfaces and their inactivation with biocidal agents. J Hosp Infect. 2020; 104 (3): 246-51.

29. van Doremalen N, Bushmaker T, Morris DH, Holbrook MG Gamble A, Williamson BN, et al. Aerosol and surface stability of SARS-CoV-2 as compared with SARS-CoV-1. N Eng J Med. 2020; 382 (16): 1564-7.

30. Leah FM, Plucinski MM, Marston BJ, Kurbatova EV, Knust B, Murray EL, et al. Public health responses to COVID-19 outbreaks on cruise ships - worldwide, February-March 2020. MMWR Morb Mortal Wkly Rep. 2020; 69 (12): 347-52.

31. Ansari SA, Springthorpe VS, Sattar SA, Rivard S, Rahman M. Potential role of hands in the spread of respiratory viral infections: studies with human parainfluenza virus 3 and rhinovirus 14. J Clin Microbiol. 1991; 29 (10): 2115-9.

32. Cevik M, Tate M, Lloyd O, Maraolo AE, Schafers J, Ho A. SARSCoV-2, SARS-CoV, and MERS-CoV viral load dynamics, duration of viral shedding, and infectiousness: a systematic review and meta-analysis. Lancet Microbe. 2021; 2: e13-22.

33. Davis GG, Williamson AK. Risk of Coronavirus Disease 2019 transmission during autopsy. Arch Pathol Lab Med. 2020; 144
(12): $1445 a-1445$.

34. Nakamura M, Tojo M, Takaso M, Hitosugi M. A regional approach for infection prevention in death investigations during the COVID-19 era. Leg Med (Tokyo). 2021; 48: 101829.

35. Centre for Health Protection. Precautions for Handling and Disposal of Dead Bodies, Hong Kong, China, 2020. Available from: https://www.chp.gov.hk/files/pdf/grp-guideline-hp-icprecautions_for_handling_and_disposal_of_dead_bodies_en.pdf.

36. Government of India Ministry of Health \& Family Welfare Directorate General of Health Services. COVID-19: Guidelines on dead body management, India, 2020. Available from: https://www.mohfw. gov.in/pdf/1584423700568_COVID19GuidelinesonDeadbodyma nagement.pdf.

37. Centers for Disease Control and Prevention. Collection and Submission of Postmortem Specimens from Deceased Persons with Known or Suspected COVID-19 (Postmortem Guidance). Available from: https://www.cdc.gov/coronavirus/2019-ncov/ hcp/guidance-postmortem-specimens.html.

38. Rijksinstituut voor Volksgezondheid en Milieu. COVID-19 richtlijn (guideline). Available from: https://lci.rivm.nl/richtlijnen/covid-19.

39. Health and Safety Executive. Managing infection risks when handling the deceased. Guidance for the mortuary, post-mortem room and funeral premises, and during exhumation. Available from: https://www.hse.gov.uk/pUbns/priced/hsg283.pdf.

40. European Centre for Disease Prevention and Control. Considerations related to the safe handling of bodies of deceased persons with suspected or confirmed COVID-19, Europe, 2020. Available from: https://www.ecdc.europa.eu/en/publications-data/ considerations-related-safe-handling-bodies-deceased-personssuspected-or.

41. WHO Guidelines. Infection prevention and control of epidemic- and pandemic-prone acute respiratory infections in health care - WHO Guidelines. Available from: https://apps.who.int/iris/bitstream/ha ndle/10665/112656/9789241507134 eng.pdf?sequence=1.

42. Keten D, Okdemir E, Keten A. Precautions in postmortem examinations in Covid-19 - Related deaths: Recommendations from Germany. J Forensic Leg Med. 2020; 73: 102000.

43. Франк Г. А., Ковалев А. В., Грибунов Ю. П., Заславский Г. И., Кильдюшов Е. М., Ягмуров О. Д. и др. Исследование умерших с подозрением на коронавирусную инфекцию (COVID-19). В сборнике: Временные методические рекомендации. Версия 22 (23.07.2020). М., 2020; 428 c.

44. Временные методические рекомендации: профилактика, диагностика и лечение новой коронавирусной инфекции (COVID-19). Версия 10 (08.02.2021). М., 2021; 262 с.

45. Зайратьянц О. В., Каниболоцкий А. А., Михалева Л. М., Мишнев О. Д., Савелов Н. С., Авдалян А. М. и др. Новая коронавирусная инфекция (COVID-19). Организация работь патологоанатомической службы. В сборнике: Временные методические рекомендации. Версия 3 (15.11.2020). М., 2020; 36 c.

46. Hanley B, Lucas SB, Youd E, Swift B, Osborn M. Autopsy in suspected COVID-19 cases. J Clin Pathol. 2020; 73: 239-42.

47. Monteiro RAA, Duarte-Neto AN, Silva LFFD, Oliveira EP, Filho JT, Santos GABD, et al. Ultrasound-guided minimally invasive autopsies: A protocol for the study of pulmonary and systemic involvement of COVID-19. Clinics (Sao Paulo). 2020; 75: e1972.

48. Roberts IS, Benamore RE, Benbow EW, Lee SH, Harris JN, Jackson $A$, et al. Post-mortem imaging as an alternative to autopsy in the diagnosis of adult deaths: a validation study. Lancet. 2012; 379 (9811): 136-42.

49. Kniep I, Lutter M, Ron A, Edler C, Püschel K, Ittrich H, et al. Postmortem imaging of the lung in cases of COVID-19 deaths. Radiologe. 2020; 60 (10): 927-33.

50. Туманова У. Н., Ляпин В. М., Быченко В. Г., Щеголев А. И., Сухих Г. Т. Посмертная МРТ для диагностики врожденной пневмонии. Вестник Российского государственного медицинского университета. 2016; 4: 48-55.

51. Туманова У. Н., Щеголев А. И. Возможности и ограничения виртуальной аутопсии в неонатологии. REJR. 2017; 7 (1): 20-33.

52. Kanchan T, Shrestha R, Krishan K. Post-mortem ultrasonography: a safer alternative to autopsies in COVID-19 deaths. J Ultrasound. 2020 Oct $31 ; 1-2$. 